\title{
Isolasi dan Aktivitas Antibakteri Aktinomisetes Asal Tanah Gambut Riau
}

\author{
Tetty Marta Linda, Rodesia Mustika Roza, Rola Yuliati, dan Wahyuliyanti \\ Laboratorium Mikrobiologi, Jurusan Biologi FMIPA Universitas Riau, Pekanbaru 28293 \\ Tel. +62 (0) 761-63273 Fax.0761-63279, e-mail: tetty.martalinda@yahoo.com
}

Diterima 05-05-2007 Disetujui 18-09-2007

\begin{abstract}
The aims of this study are to isolate actinomycetes from peat soil samples, to determine the ability of actinomycetes to inhibit the growth of Gram positive bacteria (Bacillus subtilis and Staphylococcus aureus) and Gram negative bacteria (Escherichia coli and Pseudomonas sp.). A total of 14 actinomycetes strains were recovered from peat soil samples using pour plate method with Starch Casein Agar. The results showed that 11 isolates were active against $B$. subtilis, 8 isolates against $S$. aureus, 8 isolates were active against $E$. coli and 8 isolates against Pseudomonas sp. Two isolates (SM 1.3 and SM 1.6) were active against all bacterial targets.
\end{abstract}

Keywords: actinomycetes, antibacterial, peat soil, Riau

\section{PENDAHULUAN}

Aktinomisetes merupakan mikroorganisme saprofit, bersifat Gram positif berfilamen hidup tersebar di dalam tanah, air dan tumbuhan. Aktinomisetes menghasilkan sejumlah besar substansi esensial yang banyak digunakan dalam bidang kesehatan seperti antibiotik, enzim, imunomodulator dan agen kemoterapi. Selain itu, aktinomisetes juga banyak digunakan dalam bidang pertanian sebagai pengendali hayati dan bahan tambahan pada makanan (Moncheva et al, 2002).

Menurut Singh dan Agrawal (2001) bakteri secara umum dikelompokkan berdasarkan komposisi $\mathrm{G}+\mathrm{C}$. Kelompok bakteri dengan $\mathrm{G}+\mathrm{C}$ rendah seperti Bacillus, Clostridium, Sthapylococcus, dan Streptococcus. Sedangkan kelompok bakteri dengan $\mathrm{G}+\mathrm{C}$ tinggi $(>55 \%)$ adalah aktinomisetes. Aktinomisetes muda hanya terdiri dari struktur hifa, koloni memiliki warna yang buram atau opak, mengkilap dan melekat kuat pada medium agar. Aktinomisetes dewasa memiliki karakteristik permukaan koloni bertepung, kasar dan keriput (Holt et al, 1994). Selain permukaan yang bertepung, aktinomisetes juga memiliki warna yang mudah larut dalam air dan mengeluarkan aroma tanah atau serasah.

Moncheva et al, (2002) berhasil mengisolasi 47 isolat aktinomisetes yang berasal dari tanah di Antartika, 17 isolat memperlihatkan aktivitas antagonis terhadap bakteri Gram positif dan bakteri Gram negatif. Pandey et al, (2002) berhasil membuktikan adanya aktivitas antibakteri dari isolat aktinomisetes asal tanah di Nepal terhadap bakteri patogen Bacillus subtilis,
Sthapylococcus aureus, dan E. coli. Di pihak lain, Oskay et al. (2004) mengisolasi kelompok aktinomisetes yang berasal dari tanah di Propinsi Manisa-Turki. Isolat aktinomistes tersebut memiliki aktivitas antibakteri terhadap bakteri patogen $B$. subtilis, Klebsiella pneumoniae, Enterococcus faecalis, S. aureus, E. coli, dan Sarcina lutea. Isolatisolat aktinomisetes yang memiliki aktivitas terhadap bakteri-bakteri jenis tertentu sebagian besar berasal dari tanah. Kondisi lingkungan yang berbeda akan diperoleh keragaman dari aktinomisetes .

Tanah gambut merupakan tanah yang terbentuk dari hasil dekomposisi tidak sempurna sisa-sisa tumbuhan yang membusuk dengan kadar bahan organik sangat tinggi dan $\mathrm{pH}$ rendah (Muktamar \& Adiprasetyo 1993). Propinsi Riau memiliki 4,3 juta ha potensi tanah gambut yang penyebarannya hampir di setiap Kota dan Kabupaten dengan ketebalan gambut sekitar 3-10 m. Hasil analisis kimia diperoleh komposisi tanah gambut Riau dengan kadar $\mathrm{pH} 3,1$, karbon 44,8\%, hidrogen 1,32\%, C/N 34\%, Mg 0,74\%, sulfur 0,15\%, Fe 6071 ppm, Zn 17,5 ppm, Pb 2,05 ppm (Balitbang Riau 2001).

Pengisolasian aktinomisetes dari tanah gambut Riau diharapkan akan diperoleh isolat-isolat aktinomisetes potensial. Isolat-isolat yang diperoleh bukan hanya dimanfaatkan untuk pertanian dan industri tetapi juga dapat dimanfaatkan di bidang kesehatan seperti anti kanker, antitumor, antiaging dan antibiotik (Crueger \& Crueger 1984). Oleh karena beragamnya manfaat dari aktinomisetes tersebut mendorong peneliti untuk mengisolasi aktinomisetes yang dapat 
dimanfaatkan sebagai senyawa antibakteri dan agen kemoterapi yang saat ini sangat dibutuhkan dalam dunia kesehatan.

Penelitian ini bertujuan untuk mengisolasi dan mengetahui aktivitas aktinomisetes dari tanah gambut Riau terhadap bakteri Gram positif dan Gram negatif.

\section{BAHAN DAN METODE}

Koleksi sampel. Sampel tanah gambut berasal dari Desa Sungai Mempura-Siak, Riau dengan kondisi daerah belum pernah terolah dan masih didominasi oleh vegetasi alami gambut seperti paku-pakuan, Nasturtium indicum, Uncaria sp. dan serasah yang terdapat di permukaan tanah. Sampel tanah diambil sebanyak 250 g pada 5 plot tanah yang berukuran $1 \times 1 \mathrm{~m}$, dengan 2 kali ulangan pada setiap plot. Tanah diambil pada kedalaman 5-15 cm (Oskay et al, 2004). Sampel tanah dimasukkan ke dalam plastik lalu disimpan pada refrigerator sebelum isolasi dikerjakan.

Isolasi aktinomisetes. Sampel tanah gambut sebanyak $1 \mathrm{~g}$ dimasukkan ke dalam tabung reaksi yang telah berisi garam fisiologis $0,85 \%$ sebanyak $9 \mathrm{ml}$. Larutan divortek sampai homogen. Dilakukan pengenceran bertingkat hingga mencapai pengenceran $10^{-3}$. Sebanyak $100 \mu$ l suspensi yang telah diencerkan ditumbuhkan secara pour plate di dalam medium Starch Casein Agar (SCA) yang mengandung $250 \mu \mathrm{g} / \mathrm{ml}$ nistatin. Cawan petri diinkubasi pada suhu $30^{\circ} \mathrm{C}$ selama 7-14 hari. Selanjutnya dilakukan pemurniaan terhadap koloni yang tumbuh untuk mendapatkan isolat yang murni.

Karakterisasi. Isolat yang telah murni selanjutnya dilakukan pengamatan morfologi dari isolat yang tumbuh, meliputi bentuk koloni, elevasi, warna koloni, tepian koloni, diameter koloni, bau dan konsistensi. Kemudian dilakukan pewarnaan Gram untuk memastikan isolat yang tumbuh pada medium tersebut adalah isolat aktinomisetes dengan sifat Gram positif yang berfilamen (Holt et al, 1994).

Uji Antibakteri. Bakteri uji yang digunakan adalah B. subtilis dan S. aureus, E. coli, dan Pseudomonas sp. yang diperoleh dari Laboratorium Mikrobiologi FMIPA Universitas Riau. Aktivitas aktinomisetes terhadap bakteri uji dilihat pada medium Nutrien Agar (NA). Sebanyak 1 ose bakteri uji dimasukkan ke dalam $6 \mathrm{ml}$ larutan garam fisiologis $0,85 \%$ dengan nilai kerapatan optiknya $\mathrm{OD}_{600} \mathrm{e} \cdot 0,500$ (Döring et al, 2001). Sebanyak
$2 \mathrm{ml}$ dari masing-masing stok inokulum bakteri uji di masukkan ke dalam $200 \mathrm{ml}$ medium NA $\left(45^{\circ} \mathrm{C}\right)$, dan masing-masing disebar ke dalam cawan petri. Setelah mengeras ditotolkan isolat aktinomisetes menggunakan tusuk gigi steril. Selanjutnya diinkubasi pada suhu $30^{\circ} \mathrm{C}$ selama 7 hari.

Analisis data. Data dianalisa secara deskriptif berdasarkan pengamatan makroskopik dan mikroskopik dari masing-masing isolat aktinomisetes. Aktivitas aktinomisetes terhadap bakteri target diukur berdasarkan uji nilai tengah (median) dari zona bening yang terbentuk.

\section{HASIL DAN PEMBAHASAN}

Hasil isolasi aktinomisetes dari sampel tanah gambut Desa Sungai Mempura-Siak, Riau menggunakan medium SCA diperoleh 14 isolat. Isolat yang berhasil didapatkan dari masing-masing sampel tanah gambut berbeda-beda seperti pada Tabel 1. pH sampel tanah gambut yang asam $(\mathrm{pH} 3-3,4)$ tidak berhasil diisolat aktinomisetes. Menurut Hanafiah (2005), perbedaan temperatur dan $\mathrm{pH}$ tanah memicu keanekaragaman hayati karena masing-masing mikroorganisme memiliki temperatur tumbuh dan $\mathrm{pH}$ optimum yang berbeda-beda. Dhanasekaran et al, (2005) telah mengisolasi aktinomisetes asal tanah di India dengan kondisi $\mathrm{pH}$ antara 8,03 hingga 8,06 menggunakan medium SCA. Hasil isolasinya diperoleh 17 isolat aktinomisetes. $\mathrm{pH}$ untuk pertumbuhan aktinomisetes antara pH 4-8. Menurut Alexander (1977),

Tabel 1. Isolat aktinomisetes dan kondisi lingkungan lokasi pengambilan sampel Desa Sungai Mempura

\begin{tabular}{|c|c|c|c|}
\hline Plot & Isolat & $\mathrm{pH}$ & Suhu \\
\hline \multirow{8}{*}{1} & SM 1.1 & \multirow{8}{*}{4,8} & \multirow{8}{*}{$28^{\circ} \mathrm{C}$} \\
\hline & SM 1.2 & & \\
\hline & SM 1.3 & & \\
\hline & SM 1.4 & & \\
\hline & SM 1.5 & & \\
\hline & SM 1.6 & & \\
\hline & SM 1.7 & & \\
\hline & SM 1.8 & & \\
\hline \multirow{5}{*}{ II } & SM 2.1 & \multirow{5}{*}{5,15} & \multirow{5}{*}{$30^{\circ} \mathrm{C}$} \\
\hline & SM 2.2 & & \\
\hline & SM 2.3 & & \\
\hline & SM 2.4 & & \\
\hline & SM 2.5 & & \\
\hline III & SM 3.1 & 4,9 & $33^{0} \mathrm{C}$ \\
\hline IV & - & 3,4 & $28^{\circ} \mathrm{C}$ \\
\hline V & - & 3,0 & $28^{\circ} \mathrm{C}$ \\
\hline
\end{tabular}

Ket: SM 1.1 = Sungai Mempura plot 1 sampel 1 
pada $\mathrm{pH}$ rendah mikroorganisme tanah lebih dominan ditumbuhi oleh fungi dibandingkan dengan bakteri dan aktinomisetes.

Karakterisasi Aktinomisetes. Isolat aktinomisetes yang berhasil diisolasi masing-masing memperlihatkan ciri-ciri morfologi yang berbeda-beda. Keanekaragaman isolat aktinomisetes yang ditemukan bergantung pada faktor nutrisi yang tersedia di lokasi pengambilan sampel, suhu dan $\mathrm{pH}$ sampel. Menurut Lo et al, (2002) keanekaragaman mikroorganisme yang diperoleh dari tanah didasarkan pengaruh kandungan nutrisi di dalam tanah dan jenis tanaman yang terdapat pada tanah tersebut. Hasil penelitian Singh et al, (2001) di pegunungan Everest yang memiliki suhu rendah berhasil diisolasi 68 isolat aktinomisetes dari sampel tanah. Isolat aktinomisetes tersebut, terdiri dari 48 aktinomisetes termasuk dalam 9 genera yang berbeda dengan ciri khas perbedaan warna sporanya. Isolat aktinomisetes yang berhasil diisolasi dari tanah gambut asal desa Sungai Mempura-Siak, Riau menunjukkan karakterisasi seperti pada Tabel 2. Ciri-ciri tersebut memperlihatkan perbedaan masing-masing isolat. Semua isolat aktinomisetes yang ditumbuhkan dalam medium SCA mengeluarkan aroma serasah. Menurut Alexander (1977), bau serasah atau tanah yang dikeluarkan oleh isolat aktinomisetes merupakan hasil metabolisme yang terbentuk selama pertumbuhannya berupa gas yang disebut geosmin yang merupakan salah satu ciri khas yang dapat membedakan aktinomisetes dari mikroorganisme lain.

Semua isolat aktinomisetes dari sampel tanah gambut Riau memiliki warna yang beragam. Menurut Lo et al, (2000), keanekaragaman warna aktinomisetes disebabkan oleh pigmen rantai spora yang dimiliki aktinomisetes. Pigmennya mudah larut dalam air dan berdifusi ke dalam medium. Singh et al, (2001) melakukan isolasi aktinomisetes dari sampel tanah di Gunung Everest menggunakan medium SCA, GAA (Glycerol Arginin Agar), dan ASA (Alanine Starch Agar). Isolasi tersebut diperoleh 461 isolat aktinomisetes dengan warna yang berbeda-beda seperti kuning, kekuning-kuningan, putih, keputih-putihan, hitam, kehitam-hitaman, hijau, kehijau-hijauan hingga biru.

Aktinomisetes memiliki permukaan koloni yang bertepung seperti pada Gambar 1. Tepung ini mulai terlihat pada isolat aktinomisetes yang berumur 7 hari.

Tabel 2. Karakterisasi isolat aktinomisetes dari Desa Sungai Mempura-Siak, Riau

\begin{tabular}{|c|c|c|c|c|c|c|c|c|c|c|}
\hline \multirow{2}{*}{$\begin{array}{l}\mathrm{N} \\
\mathrm{O}\end{array}$} & \multirow{2}{*}{ Isolat } & \multicolumn{9}{|c|}{ Karakterisasi } \\
\hline & & Permukaan & Koloni & Tepian & Elevasi & Warna & Konsistensi & Bau & Diameter & Gram \\
\hline 1 & SM 1.1 & Bertepung & $\begin{array}{c}\text { Bulat } \\
\text { konsentris }\end{array}$ & Berombak & $\begin{array}{c}\text { Cembung } \\
\text { mencengkeram } \\
\text { ke medium }\end{array}$ & $\begin{array}{c}\text { Putih } \\
\text { kekuningan }\end{array}$ & Melekat & serasah & $0,93 \mathrm{~cm}$ & positif \\
\hline 2 & SM 1.2 & Bertepung & Bulat & Berombak & Cembung & Cokelat & Melekat & serasah & $0,3 \mathrm{~cm}$ & positif \\
\hline 3 & SM 1.3 & Bertepung & Bulat & Licin & Cembung & Cokelat keabuan & Melekat & serasah & $0,17 \mathrm{~cm}$ & positif \\
\hline 4 & SM 1.4 & Bertepung & $\begin{array}{c}\text { Bulat } \\
\text { konsentris }\end{array}$ & Berombak & Berbukit-bukit & Putih keabuan & Melekat & serasah & $0,33 \mathrm{~cm}$ & positif \\
\hline 5 & SM 1.5 & Bertepung & Bulat & Licin & Cembung & Putih keabuan & Melekat & serasah & $0,1 \mathrm{~cm}$ & positif \\
\hline 6 & SM 1.6 & Bertepung & Bulat & Licin & $\begin{array}{c}\text { Cembung } \\
\text { mencengkeram } \\
\text { ke medium }\end{array}$ & Krem & Melekat & serasah & $0,3 \mathrm{~cm}$ & positif \\
\hline 7 & SM 1.7 & Bertepung & Bulat & Berombak & Cembung & Putih & Melekat & serasah & $0,4 \mathrm{~cm}$ & positif \\
\hline 8 & SM 1.8 & Bertepung & Bulat & Berombak & Cembung & $\begin{array}{l}\text { Kuning } \\
\text { kehijauan }\end{array}$ & Melekat & serasah & $0,21 \mathrm{~cm}$ & positif \\
\hline 9 & SM 2.1 & Bertepung & Bulat & Licin & $\begin{array}{l}\text { Cembung } \\
\text { mencengkeram } \\
\text { ke medium }\end{array}$ & Cokelat keabuan & Melekat & serasah & $0,38 \mathrm{~cm}$ & positif \\
\hline 10 & SM 2.2 & Bertepung & Bulat & Berombak & Cembung & Cokelat keabuan & Melekat & serasah & $0,5 \mathrm{~cm}$ & positif \\
\hline 11 & SM 2.3 & Bertepung & Bulat & Berombak & Cembung & $\begin{array}{c}\text { Krem } \\
\text { kemerahan }\end{array}$ & Melekat & serasah & $0,4 \mathrm{~cm}$ & positif \\
\hline 12 & SM 2.4 & Bertepung & $\begin{array}{c}\text { Bulat } \\
\text { konsentris }\end{array}$ & Berombak & Cembung & $\begin{array}{c}\text { Krem } \\
\text { kemerahan }\end{array}$ & Melekat & serasah & $0,5 \mathrm{~cm}$ & positif \\
\hline 13 & SM 2.5 & Bertepung & Bulat & Licin & $\begin{array}{l}\text { Cembung } \\
\text { mencengkeram } \\
\text { ke medium }\end{array}$ & $\begin{array}{c}\text { Putih } \\
\text { kekuningan }\end{array}$ & Melekat & serasah & $0,3 \mathrm{~cm}$ & positif \\
\hline 14 & SM 3.1 & Bertepung & Bulat & Licin & $\begin{array}{l}\text { Cembung } \\
\text { mencengkeram } \\
\text { ke medium }\end{array}$ & Putih kemerahan & Melekat & serasah & $0,5 \mathrm{~cm}$ & positif \\
\hline
\end{tabular}




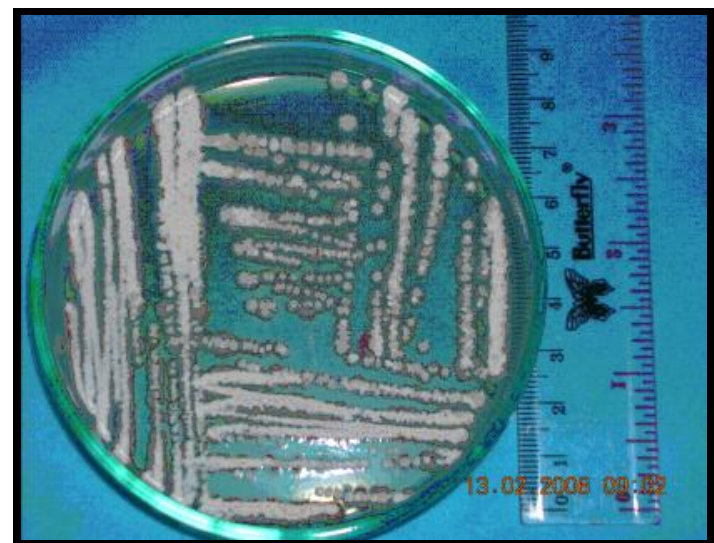

Gambar 1. Pertumbuhan isolat aktinomisetes dalam medium SCA umur 8 hari pada $30^{\circ} \mathrm{C}$ dengan permukaan bertepung

Tepung yang muncul pada permukaan isolat aktinomisetes ini merupakan kumpulan dari spora-spora aktinomisetes itu sendiri. Menurut Holt et al, (1994), hal ini disebabkan karena aktinomisetes memiliki miselium aerial yang sporanya membutuhkan waktu 7-14 hari untuk berkembang. Berdasarkan pewarnaan Gram yang dilakukan terhadap ke-14 isolat aktinomisetes umur 24 jam terlihat bahwa aktinomisetes termasuk ke dalam kelompok bakteri Gram positif dengan sel berfilamen, berwarna ungu. Beberapa dari isolat aktinomisetes memperlihatkan filamen berbentuk spiral, yaitu SM 1.2, SM 1.3, dan SM 2.3. Filamen yang berbentuk spiral merupakan salah satu ciri-ciri dari aktinomisetes kelompok Streptomyces.

Aktivitas Antibakteri Aktinomisetes. Isolat aktinomisetes yang berhasil diisolasi umumnya menunjukkan kemampuan untuk menghambat pertumbuhan bakteri target yaitu B. subtilis, $S$. aureus, E. Coli, dan Pseudomonas sp. yang ditandai dengan terbentuknya zona bening di sekitar isolat uji seperti pada Gambar 2. Daya hambat isolat aktinomisetes terhadap bakteri target dapat dilihat pada Tabel 3 .

Isolat aktinomisetes dari Desa Sungai MempuraSiak, Riau umumnya mampu menghambat pertumbuhan bakteri target Gram positif dan Gram negatif. Dua isolat aktinomisetes mampu menghambat semua bakteri uji yang digunakan yaitu isolat dengan kode SM 1.3 dan SM 1.6, sedangkan isolat yang mampu menghambat salah satu dari keempat bakteri uji yang digunakan yaitu isolat SM 1.1 dan SM 2.3. Isolat SM 3.1 tidak mampu menghambat semua bakteri uji yang digunakan pada penelitian ini.

Aktinomisetes yang mampu menghambat pertumbuhan bakteri Gram positif dan Gram negatif

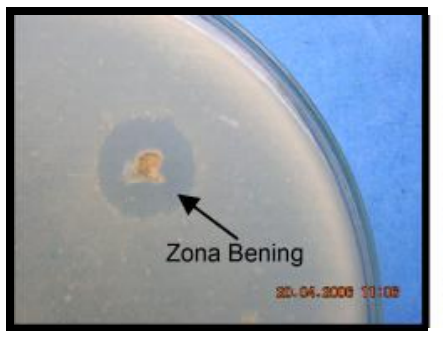

(a)

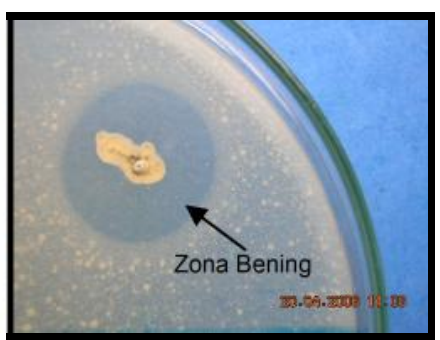

(b)
Gambar 2. Pembentukan zona bening isolat aktinomisetes terhadap bakteri uji pada medium NA (a) Isolat SM 1.6 Terhadap B. subtilis dan (b) Isolat SM 1.3 Terhadap $S$. aureus

Tabel 3. Daya hambat isolat aktinomisetes terhadap bakteri target Gram Positif dan Gram Negatif

\begin{tabular}{|c|c|c|c|c|}
\hline \multirow{3}{*}{$\begin{array}{l}\text { Kode } \\
\text { Isolat }\end{array}$} & \multicolumn{4}{|c|}{$\begin{array}{l}\text { Reaksi Terhadap Bakteri Target } \\
\text { (zona bening dalam } \mathrm{mm} \text { ) }\end{array}$} \\
\hline & \multicolumn{2}{|c|}{ Bakteri Gram Positif } & \multicolumn{2}{|c|}{ Bakteri Gram Negatif } \\
\hline & B. subtilis & S. aureus & E. coli & Pseudomonas sp. \\
\hline SM 1.1 & 0 & 3,4 & 0 & 0 \\
\hline SM 1.2 & 6 & 2,9 & 0 & 3,8 \\
\hline SM 1.3 & 3,3 & 13 & 6,2 & 4,8 \\
\hline SM 1.4 & 7 & 4 & 0,9 & 0 \\
\hline SM 1.5 & 6,5 & 0 & 0 & 6 \\
\hline SM 1.6 & 6,3 & 10 & 8,9 & 4,5 \\
\hline SM 1.7 & 7,9 & 0 & 3,5 & 7 \\
\hline SM 1.8 & 6,8 & 7 & 0 & 2 \\
\hline SM 2.1 & 4,7 & 0 & 1,3 & 4 \\
\hline SM 2.2 & 7,5 & 0 & 2,5 & 0 \\
\hline SM 2.3 & 0 & 0 & 0 & 1,7 \\
\hline SM 2.4 & 8 & 4,1 & 3,4 & 0 \\
\hline SM 2.5 & 6 & 9,6 & 14,2 & 0 \\
\hline SM 3.1 & 0 & 0 & 0 & 0 \\
\hline
\end{tabular}

digolongkan ke dalam kelompok aktinomisetes yang memiliki antibiotik berspektrum luas sedangkan aktinomisetes yang hanya mampu menghambat pertumbuhan salah satu dari bakteri uji Gram positif atau Gram negatif saja dikelompokkan ke dalam jenis aktinomisetes dengan antibiotik berspektrum sempit (Crueger \& Crueger 1984). Antibiotik tersebut merupakan salah satu produk metabolit sekunder yang dihasilkan oleh mikroorganisme. Berdasarkan penelitian-penelitian yang telah dilakukan membuktikan bahwa aktinomisetes termasuk kelompok mikroorganisme tanah yang sangat banyak menghasilkan antibiotik yang mampu menghambat pertumbuhan bakteri Gram positif ataupun bakteri Gram negatif (Moncheva et al, 2002).

Menurut Rao (1994), kemampuan antagonisme merupakan gejala umum yang menunjukkan konsekuensi dihasilkannya antibiotik. Pada penelitian ini zona bening mulai terbentuk dan dapat terlihat dengan jelas setelah inkubasi umur 24 jam. Hal ini 
disebabkan karena bakteri uji yang digunakan memiliki waktu pertumbuhan optimum 18-24 jam. Sedangkan medium yang digunakan merupakan medium umum untuk pertumbuhan bakteri yaitu NA. Menurut Madigan et al, (2003) pembentukan metabolit sekunder sangat tergantung dari kondisi pertumbuhan salah satu komposisi medium.

Berdasarkan penelitian uji daya hambat isolat aktinomisetes yang pernah dilakukan oleh Oskay et al, (2004) dari 50 isolat aktinomisetes yang diisolasi, 17 diantaranya berpotensi dalam menghambat pertumbuhan Pseudomonas viridiflora, Erwinia amylovora, B. subtilis, S. aureus, E. coli, dan Sarcina lutea. Dari penelitian tersebut, diameter zona bening terbesar yaitu $32 \mathrm{~mm}$ dan terkecil yaitu $2 \mathrm{~mm}$. Di pihak lain, Naidenova \& Vladimirova (2002) melakukan uji daya hambat isolat aktinomisetes dari sampel tanah, air dan serasah di Bulgaria terhadap E. coli dan $B$. subtilis. Hasil pengujiannya menunjukkan zona bening terbesar $22 \mathrm{~mm}$ dan zona bening terkecil $16 \mathrm{~mm}$. Jika dibandingkan dengan penelitian pengujian daya hambat isolat aktinomisetes asal Desa Sungai Mempura-Siak, Riau terhadap 14 isolat diperoleh zona bening terbesar yaitu 14,2 mm dan zona bening terkecil sebesar 0,9 $\mathrm{mm}$.

Pengelompokkan aktivitas isolat aktinomisetes berdasarkan uji nilai tengah (median) dapat dilihat pada Tabel 4. Aktivitas isolat aktinomisetes terhadap $B$. subtilis yang termasuk dalam kriteria tinggi $(>7,36 \mathrm{~mm})$ ada $27,27 \%$ yaitu isolat SM 1.7, SM 2.2 dan SM 2.4. Isolat SM 1.2, SM 1.4, SM 1.5, SM 1.8 dan SM 2.5 termasuk kriteria sedang (5,71-7,36 mm) dengan persentase $54,54 \%$. Isolat dengan kriteria rendah (< $5,71 \mathrm{~mm}$ ) ada $18,18 \%$ yaitu isolat SM 1.3, SM 1.6 dan SM 2.1.

Aktivitas isolat aktinomisetes terhadap $S$. aureus yang termasuk dalam kriteria tinggi (>10,52 mm) adalah isolat SM 1.3 dengan persentase sebesar $12,5 \%$. Isolat dengan kriteria sedang ada $37,5 \%$ pada isolat SM 1.6 , SM 1.8, dan SM 2.5. Isolat dengan kriteria rendah (< $5,44 \mathrm{~mm}$ ) ada 50\% yaitu SM 1.1, SM 1.2, SM 1.4, dan SM 2.4 .

Aktivitas isolat aktinomisetes terhadap $E$. coli yang termasuk dalam kriteria tinggi (>10,92 mm) yaitu isolat SM 2.5 sebesar 12,5\%. Isolat dengan kriteria sedang (4,24-10,92 mm) ada 25\% pada isolat SM 1.3 dan SM 1.6. Isolat dengan kriteria rendah $(<4,24 \mathrm{~mm})$
Tabel 4. Kriteria isolat aktinomisetes berdasarkan uji nilai tengah (median) terhadap masing-masing pertumbuhan bakteri target



\begin{tabular}{lcccc}
\hline SM 1.1 & - & $*$ & - & - \\
SM 1.2 & $* * *$ & $*$ & - & $* * *$ \\
SM 1.3 & $*$ & $* * * *$ & $* * *$ & $* * *$ \\
SM 1.4 & $* * *$ & $*$ & $*$ & - \\
SM 1.5 & $* * *$ & - & - & $* * * *$ \\
SM 1.6 & $*$ & $* * *$ & $* * *$ & $* * *$ \\
SM 1.7 & $* * * *$ & - & $*$ & $* * * *$ \\
SM 1.8 & $* * *$ & $* * *$ & - & $*$ \\
SM 2.1 & $*$ & - & $*$ & $* *$ \\
SM 2.2 & $* * * *$ & - & $*$ & - \\
SM 2.3 & - & - & - & - \\
SM 2.4 & $* * * * *$ & $*$ & $*$ & - \\
SM 2.5 & $* * *$ & $* * *$ & $* * * *$ & - \\
SM 3.1 & - & - & - & \\
\hline Keterangan & & & & - \\
\hline
\end{tabular}

\section{Keterangan :}

$\star \star \star \star \star \quad$ : kriteria tinggi

$\star * * \quad:$ kriteria sedang

* $\quad$ : kriteria rendah

: tidak memiliki daya hambat

ada $62,5 \%$ yaitu SM 1.4, SM 1.7, SM 2.1, SM 2.2, dan SM 2.4 .

Aktivitas isolat aktinomisetes terhadap Pseudomonas sp. yang termasuk dalam kriteria tinggi $(>5,99 \mathrm{~mm})$ yaitu isolat SM 1.5 dan SM 1.7 sebesar $25 \%$. Isolat dengan kriteria sedang $(3,13-5,99 \mathrm{~mm})$ ada $50 \%$ pada isolat SM 1.2, SM 1.3, SM 1.6, dan SM 2.1. Isolat dengan kriteria rendah $(<3,13 \mathrm{~mm})$ ada 25\% yaitu SM 1.8 dan SM 2.3.

Perbedaan antara konsentrasi senyawa antimikrobia yang dihasilkan oleh aktinomisetes berpengaruh terhadap ketahanan bakteri target. Senyawa antimikroba yang dihasilkan sangat mempengaruhi besar kecilnya daya hambat yang terbentuk. Selain itu tidak semua aktinomisetes memiliki kemampuan untuk menghambat pertumbuhan suatu bakteri target, tergantung dari interaksi antagonis yang terjadi antara kedua isolat.

\section{KESIMPULAN}

Berhasil diisolasi 14 isolat aktinomisetes dari tanah gambut Desa Sungai Mempura-Siak, Riau. Hasil uji nilai tengah, isolat aktinomisetes yang memiliki aktivitas tinggi terhadap $B$. subtilis adalah SM 1.7, SM 2.2, dan SM 2.4. Isolat yang memiliki aktivitas tinggi terhadap S. aureus adalah SM 1.3. Isolat aktinomisetes 
yang memiliki aktivitas tinggi terhadap E. coli adalah SM 2.5. Isolat aktinomisetes yang memiliki aktivitas tinggi terhadap Pseudomonas sp. adalah SM 1.5 dan SM 1.7. Tidak terdapat isolat aktinomisetes pada sampel tanah gambut dengan $\mathrm{pH}$ 3-3,4.

\section{UCAPAN TERIMA KASIH}

Terimakasih yang sebesar-besarnya kepada Afni Riska, Herlinda, dan Wahyulianti yang telah membantu dalam pengambilan sampel penelitian.

\section{DAFTAR PUSTAKA}

Alexander, M. 1977. Introduction to Soil Microbiology. Second Edition. New York: Cornell University.

BALITBANG Propinsi Riau. 2001. Laporan Akhir Pengembangan Pusat Riset Gambut Tropika Propinsi Riau. Pekanbaru.

Crueger, W. \& Crueger, A. 1984. Biotechnology: A Textbook of Industrial Microbiology. Madison: Science Tech, Inc.

Dhanasekaran, D., Rajakumar, G., Sivamani, P., Selvamani, A., Panneerselvam, A., \& Thajuddin, N. 2005. Screening of salt pans actinomycetes for Antibacterial agents. The Internet Journal of Microbiology 1: 1-3.

Döring, V., Mootz, H.D., Nangle, L.A., Hendrickson, T.L., Crécy-Lagard, V, Schimmel, P., \& Marlière, P. 2001 Enlarging the amino acid set of Escherichia coli by infiltration of the valine coding pathway. Journals of Optical Density of Escherichia coli 292: 501-504.
Hanafiah, K.A. 2005. Dasar-Dasar IImu Tanah. Jakarta: PT. Raja Grafindo Persada.

Holt, J.G., Krieng, N.R., Sneath, P.H.A., Staley, J.T., \& William, S.T. 1994. Bergey's Manual of Determinative Bacteriology. Ed. ke-9. Baltimore: Williams and Wilkins.

Lo, C.W., Lai, N.S., Cheah, H.Y., Wong, N.K.I., \& Ho, C.C. 2002. Actinomycetes isolated from soil sample from the croker range Sabah. ASEAN Review of Biodiversity and Environmental Conservation (ARBEC). http:// www.arbec.com.my/pdf.art21julysep02.pdf.

Madigan, M.T., Martinko, J.M., \& Parker, J. 2003. Brock Biology of Microorganisms. Tenth Edition. New Jersey: Prentice Hall International, Inc.

Moncheva, P., Tishkov, S., Dimitrova, N., Chipeva, V., Nikolova, S.A., \& Bogatzevska. 2002. Characteristics of soil Actinomycetes from Antartica. Journal of Culture Collections 3: 3-14.

Muktamar, Z. \& Adiprasetyo, T. 1993. Studi potensi lahan gambut di Propinsi Bengkulu untuk tanaman semusim. Prosiding Seminar Nasional Gambut. HGI. Jakarta.

Naidenova, M. \& Vladimirova, D. 2002. Isolation and taxonomic investigation of actinomycetes from specific biotopes in Bulgaria. Journal of Culture Collection 3: 15-24.

Oskay, M., Tamer, A.U. \& Azeri, C. 2004. Antibacterial activity of some actinomycetes isolated from farming soils of Turkey. African Journal of Biotechnology 3: 441-446.

Pandey, B., Ghimire, P. \& Agrawal, V.P. 2002. Studies on Antibacterial Activity of The Actinomycetes Isolated from The Kumbu Region of Nepal. Tribuvan University. Nepal. http:/ Igsbs.utmb.edu/microbook/images/tbl2_2.jpg.(2 Februari $\underline{2005}$

Rao S. 1994. Mikroorganisme Tanah dan Pertumbuhan Tanaman. Jakarta: Universitas Indonesia Press.

Singh, D. \& Agrawal, V.P. 2001. Biodiversity of Actinomycetes of Lobiche in Mount Everest I. http://www.nepalschools.org/ rlabb/biodiversity-of-actinomysetes-of.htm. (9 Desember $\underline{\underline{2005}}$ 